\title{
Edebiyatta Gerçekçilik ve Alımlama Estetiği
}

\section{Doç. Dr. Sefa Yüce*}

Öz

İnsan varlığı karmaşık bir yapıdır. Bu yapının iç dünyası, duygusal ve sezgisel boyutuyla edebî metinlere yansır. Edebî metin bir üst dildir. Günlük dilin daha üst basamağıdır. Bu amaçla edebî metin kurgusaldır. $\mathrm{O}$, varoluşu anlatır. Yazar, ele aldığı bir öyküyü veya hayattan bir kesiti, kendi bütünlüğü içinde sanatın dünyasında dönüştürür, onu yeniden inşa eder, kurar. Diğer sanat eserlerinde olduğu gibi edebî eserler de birden çok anlam içerir. Bir edebî eser, değerini ve önemini realiteden almaz. $\mathrm{O}$, önemini ve değerini üslubundan alır. Aslında edebî eser, hayatı üretmenin ve kurgulamanın bir aracıdır.

Sanat ve edebiyatta dile gelen, ifade edilen insanlığın değişik hâlleridir.Sanatı bir yansıtma aracı olarak görenler, realiteden, hayatın gerçeğinden hareket edenlerdir. Onlara göre sanatın yönü ve yüzü daima hayata dönüktür. Sanatı anlamak bir nevi insanı anlamaktır. Sanatkâr, kendi döneminin ruhunu ve dokusunu eserine yansitır. Bunu yansittrken kültürden kültüre ve döneme ve çağa göre ölçütler değişkenlik gösterir.Aydınlanma Çağı ile birlikte felsefenin gelişim,i sanatları da derinden etkiler. $\mathrm{Bu}$ çağdan itibaren felsefi derinlik ve felsefi bakış açısı, edebiyat kuramlarında ve edebî eserlerde kendini belirgin bir biçimde hissettirir. Hayat ve gerçeklik, toplumsal gerçekçilik gibi oluşumlar da bu bakış açısının sonucudur. Bu bakış açısının içine alımlama estetiğini de dâhil etmek gerekir.Alımlama estetiği çağdaş bir edebiyat kuramıdır. Edebî eseri çözümleyen ve onu anlamaya çalışan okurdur. Her okur, edebî esere kendine özgü bilgi birikimi ve beklentiyle yaklaşır. Edebî eser, her okur tarafından yeniden yorumlanan ve değerlendirilen bir metindir. Bu açıdan her yorum, bir özgür etkinlik ifadesidir.

XIX. yüzyılda pozitivizmin ortaya çıkışı ve yaygınlık kazanması sanatta realizmin doğuşuna zemin hazırlar. Gerçekçilik, sanatın esası ve temelidir. Tüm sanat türleri ve özellikle edebî eserler "toplumsal ve tarihsel" gerçeklikleri yansıtırlar. Sanat eseri, kendi gerçeğini anlatır. Bu yönüyle sanat eseri, içinde bulunduğu koşulların bir ürünüdür.Her çağ ve dönem, kendi sanat eserinde fikir ve hisleriyle hayatiyet bulur. Ayrıca gerçeklik bütün unsurlarıyla tanımlanmış bir kavram da değildir.Realizm, bazı yönlerden gerçekliğin taklididir. Bir nevi hayatın "mimesis"idir. Ele alınan ve değerlendirilen bir eserin gerçekliğin "yazara göre mi, okura göre mi veya çağa göre mi tespit edileceği" hâlâ belirsiz bir

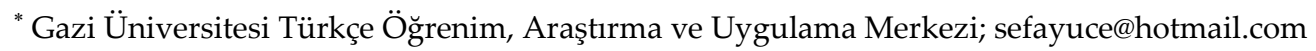


durumdur.Her toplumda söylemler değişkenlik gösterir. Edebiyat kuramları da sosyokültürel bilgi birikiminin sonucuna göre değişime uğrar.

Siyasi ve sosyal olayların gelişimi ile birlikte sanatkârlar realizmden etkilenirler. Bu etkilenmede dönemin ve devrin ruhu ile o çağa ait düşünce etkinliklerinin birikimi önemli rol oynar. Aslında Batı'da gerek kuramlar ve gerekse edebî akımlar arasında bir iç ve dış mücadelesi olduğunu görürüz. Yani bu durum felsefi ve sanat boyutunda maddi ve manevi değerlerin bir çatışması biçiminde cereyan eder.

Anahtar sözcükler: Edebiyatta gerçekçilik, üst dil, okur, realizm, pozitivizm, alımlama estetiği.

\section{Abstract}

\section{REALISM AND RECEPTION AESTHETICS IN LITERATURE}

The human existence is a complex structure. The emotional and intuitional dimensions of this structure penetrate to literature. It is higher than daily language. Thus, the literary text is fictive. It expresses the existence. The man of letters transforms a part of life or a story, in the world of art by maintaining its integrity; so she/he reconstructs and rewrites it. Like in all other art pieces, the literary pieces also have more than a single meaning. The value and importance of a literary text is not related to its loyalty to the reality, but its language and style. In fact, the literary text is the means of the creating and fictionalizing the life.

What described and expressed in art and literature is the various conditions of humanity. People considering art as a tool of reflection are the persons who act from the reality of life. According to them, the direction and face of the art always look to the life. To understand art means somehow to understand human. The artist reflects the soul and features of its own era to his/her art. The parameters for this reflection change depending on the culture and time. With the Age of Enlightenment, the development of philosophy deeply has influenced the arts, as well. Since this era, the philosophical depth and perception have been prominently seen in literary theories and pieces. The formations such as life and reality, social realism are the results of this perception. The reception aesthetics is also a part of this point of view. The reception aesthetics is a contemporary literary theory. It is the reader who scrutinizes and tries to understand the text. Each reader approaches to a text with her/his own unique knowledge and expectations. The literary work is a text that is reinterpreted and reassessed by each reader. Thus, each comment is the expression of a free activity.

The emergence of positivism in $19^{\text {th }}$ century and its common acceptance have provided a basis for the birth of realism in the art. The realism is the essence of the art. All arts and especially literature reflect the "social and historical" realities. An art work tells its own reality. In that sense, the art work is the product of the conditions which it is in. Each era and 
period survive with its ideas and feelings by means of its own art. Besides, the reality is not a concept that is fully identified with all its parts. The realism is the imitation of the reality in terms of certain aspects. It is some kind of the "mimesis" of life. The matter of the reality of a text is still an ambiguous subject, because "the condition of reality" can change depending on the author, reader and era. The discourses can differ in every society. The literary theories can also change according to the consequences of socio-cultural knowledge. The artists have been influenced by the realism with the development of social and political events.

In this context, the soul and the way of thinking of the period also play important roles. In fact, we observe that there is an internal and external struggle between the theories and literary movements in the West. In a sense, it is the clash of material and moral values in the context of philosophy and art.

Keywords: Reality in the literature, meta-language, reader, realism, positivism, reflection aesthetics.

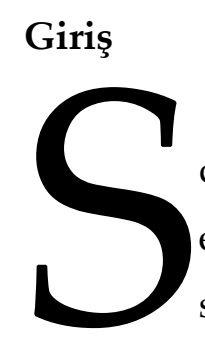

anat, insanoğlunun "yaratıcı hayal gücü"nün bir ürünüdür. Edebiyat da sanatın bir dalıdır. Edebiyat, edebî eserle önem ve değer kazanır."Edebî eser, yeni bir hayat görüşü, yeni bir perspektif veya bir değerler ve normlar sistemidir. Edebî eser, tarihi ve kültürel bir olaydır, eşsizdir, bilimsel olaylar gibi belli şartlar altında tekrarı mümkün değildir. Edebî eser, hem yaratıcı bir dehanın içinde yaşadığı kültür ortamına getirdiği bir yorumdur, hem de onun yaratılışında öz ve biçim bakımından yaşanılmış ortak bir geçmişin etkisi büyüktür. Edebî eser, bir edebiyat geleneğinin ve değerler sisteminin bir parçasıdır." (Kantarcıoğlu 1993: 3) Okurlar ve eleştirmenler, edebî eseri anlamaya çalışırlar. Edebî eseri, diğer sanat eserlerinden ayıran "ilk özellik, insan duygu ve ihtiraslarının düşünce unsurundan daha yoğun olmasıdır."(4) Bir edebiyat eserini, bir değer olarak ortaya çıkışını belirleyen "kavrayış derinliği, hayata yakınlık, biçimsel uyum, evrensellik, ahlaki duruş, kelime bazlı yaratıcılık, hayal gücü genişliği"dir." (Eagleton 2015: 189)

Platon'dan beri sanat konusu farklı bakış açılarına göre değerlendirilir. Sanat, her dönem ve devirde yeniden yorumlanır. Platon, sanatı ahlak açısından değerlendirir ve "ideal devlet"inde sanata yer vermez. Ona göre sanat, insan karakterini kötü yönde etkilemekte ve onu zafiyete düşürmektedir. Bu nedenle sanatı yasaklar. Fakat pek çok yazar ve düşünür sanatın eğitici yönünün olması gerektiğini düşünür. Tolstoy, sanatın ahlaki bir nitelik taşımasının önemine inanır, ayrıca dine de uygun olmasının gerekliliğini savunur: "İnsanın bütün yaşamı beşikten mezara kadar hep sanatla doludur. Ninniler, bilmeceler, evlerimizin süsleri, öykünmeler, fikralar, giysilerimiz, kiliselerde kullanılan gereçler, bayramlık eşyalar, 
hep sanat yapitlarıdır, sanatın etkinlik alanına giren şeylerdir. Biz duyguları yansıtan bütün insani etkinlikleri değil, bu etkinliklerden her nedense ayırdığımız ve özel anlam yüklediğimiz bazı etkinlikleri sanat olarak adlandırıyoruz." (Tolstoy 2013: 52) Tolstoy, sanatın özellikle edebiyatın önemli görevleri olduğunu belirtir. Ona göre sanatın asıl işlevi insanların barış ve huzur içinde yaşamasını temin etmektir. Bunu da ancak sanat yapabilir. Sanat vasıtasıyla geçmişin değerleri gelecek nesillere aktarılabilir. Sanatın bir diğer işlevi de zoru ve şiddeti

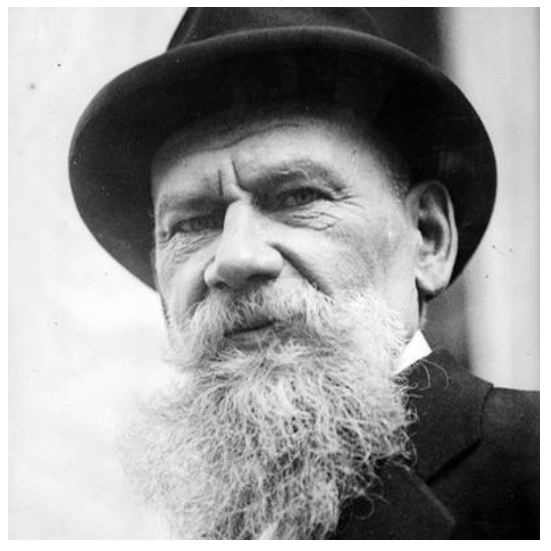

Tolstoy toplumun hayatından uzaklaştırmaktır. Tolstoy'a göre: "Sanat ne keyiftir, ne de eğlence, sanat yüce bir iştir. Sanat insan yaşamında bilinçli bilgiyi duygulara aktaran bir organdır... Gerçek bilim bu bilincin hayata uygulanışının farklı biçimlerini gösterirken, sanat bu bilinci duygulara taşımalıdır." (230)

Sanat eseri, kuramlar için bir düzenin ifadesi olarak kabul edilir. Sanat eserinde düzen nedir ve neyi ifade eder? Sanatta düzen: "Sözgelimi bir şiir, bir resim, bir müzik parçası, her şeyden önce bir düzendir. Her düzen içine birbirinden farklı parçaları alır; düzen bu parçaların çokluğuna dayanır. Bundan ötürü her sanat yapıtında çokluğa dayalı birlik söz konusudur. Bu anlayış diğer sanat felsefeleri gibi Marksist sanat felsefesi için de geçerlidir." (Tunalı 2001: 80) Sanat eseri, duygu ve hayal gücüne dayanmakla birlikte, onda karşıtları da uzlaştıran ve onları denkleştiren bir uyum söz konusudur. Sanat eserleri sağlam ve tutarlı bir mantık gerçeğine dayanır. Önemli ve değerli sanat eserleri, hem çağına tanıklık eder hem de çağını aşan niteliklere sahiptir. Bununla birlikte bir sanat eseri, asla değişmeyen ve her zaman kalıcı olan yeni değerler oluşturmak zorunda değildir. Sanat, insan tabiatının değişkenlerini ifade eder. Sanatçı da bu değişkenleri her dönemde farklı bir biçimde ifade etmeye çalışır.

Bir sanat dalı olan edebiyat, hayatı yeniden kurar ve yeniden biçimlendirir. Bir şair, bir yazar hayatı kendi dünyasında "yazma süreci"nde yeniden tanzim eder. Bu süreçle edebî eser oluşur. Edebî eser, hayatı ifade eder. "Yazarlar, şairler, seyyahlar, ressamlar, fakirliği, zenginliği, sevinci ve hüznü, ayrılığı ve kavuşmayı yeniden işeyerek bilinç düzeyine çıarırlar." (Taşdelen 2013: 45) Hayatı tekdüze ve zengin olmayan toplumların edebiyatı da bir varlık gösteremez. Çünkü her sanat eserinde sanatkârın kendi dönemi ve o dönemin dünya görüşü vardır. Biz, sanat eserleri vasıtasıyla bir toplumun maddi ve manevi değerler dünyasını anlayabiliriz. Bu konuda edebî eserler bizim en önemli dayanağımızdır. Çünkü edebiyat, aynı zamanda kültür aktarımı da yapar. Biz, geçmiş ile gelecek arasındaki bağı 
edebî eserler vasıtasıyla kurarız. Millî bilincin oluşumunda da edebiyatın çok önemli katkısı vardir.

Edebiyatın sunduğu bilgi değişken ve dönüşken bir bilgidir. İnsani bilimler gibi (psikoloji, sosyoloji, tarih, coğrafya, arkeoloji)kesin veri sunmaz. Edebî eser,kendi içinde bazen karmaşık yapı içerir. Onun dili, nesnel ya da öznel veya soyut-somut olabilir. Bu dil, yan anlamla okura zengin çağrışım imkânları sunar.

\section{Realizm-Edebiyatta Gerçekçilik}

Rönesans'la birlikte özgür düşüncenin gelişimi sanatın gelişimini hızlandırır. Fikir ve his dünyası yeni bir boyut kazanır. Önce aklı öne çıkaran anlayış, daha sonra ona tepki olarak his ve hayali gündeme taşıyan arayış birbirini takip eder. XIX yüzyılda edebî anlayışta yeni bir eğilim başlar, gerçekçilik. Bu anlayış "çağdaş sosyal realitenin objektif temsili olarak da açıklanan realizm, pozitivizmin sanat ve edebiyata yansımasıdır. Realizm (gerçekçilik) en geniş anlamı ile eşyanın ve olayların oldukları gibi tasvir edilmesidir." (Kefeli 2007: 45) Çağa göre akımlar ile kuramlar arasında genellikle birbirini tamamlayan ve besleyen unsurların olduğunu görürüz. Bu unsurlardan biri de felsefedir. Aslında "çağın felsefesinin sanat üzerindeki etkisi akım olarak ortaya çıkar ve bütün sanat türlerinde ortak özellikler çevresinde gelişir." (Özkırımlı 1981: 411)

René Wellek, gerçek kavramının tanımını felsefecilere bırakır. Ona göre: "Wimsatt ve Brooks gibi edebiyatta gerçekçiliğin hayalî olanı, peri masalı unsurlarını, alegorik ifade ve sembolik düşünce biçimlerini, soyut genellemeleri ve süslü ifade şeklini dışladığını belirtmektedir. Gerçekçi edebiyat, belli bir zaman ve mekânda,mantık ve ihtimal kanunlarına uygun olarak yer alan insan tecrübesini sebep netice ilişkisi içinde vermeyi amaçlar, kapsamı içinde mucizelere, tesadüflere ve duyularüstü gerçeklere yer vermez." (Kantarcıŏ̆lu 1993: 136) Daha çok roman alanında kendini gösteren gerçekçilik anlayışı, insan hayatını farklı dönemleriyle ele alır ve insanın ideallerine de yer verir. Bu anlayış hem yönlendirici, hem de eğitici yönüyle klasisizme de benzetilir.

Georg Lukacks, edebiyatta gerçekçiliğin kuramını en tutarlı biçimde ele alıp geliştiren eleştirmenlerden biridir. Lukacs'a göre "edebiyat bir devrin sosyal gerçeğini, sosyal gelişimini ve (bu gelişim içinde meydana gelen) sosyal çatışmaları en doğru biçimde yansıtmalıdır. Gerçekçi bir roman (bir edebî eser) sanatçının yansıttı̆̆ı tarihi devrin ruhunu, geleceğe yönelik sosyal gelişmesini yakaladığı ölçüde başarılıdır." (Kantarcıoğlu 1993: 137) Lukacs da sanatı bir yansıtma yöntemi olarak kabul eder ve kendi içinde ikiye ayırır: "Gerçekçilik ve doğalcılık. Bunlardan birincisi sosyal gerçekçiliği yansıtabilir, ikincisi yansıtamaz. Lukacs da Gorki gibi gerçekçiliği de ikiye ayırır: Eleştirel gerçeklik, toplumsal gerçekçilik (Moran 1981: 41). Fakat Georg Lukacs'ın üzerinde durduğu gerçeklik akımı ile 


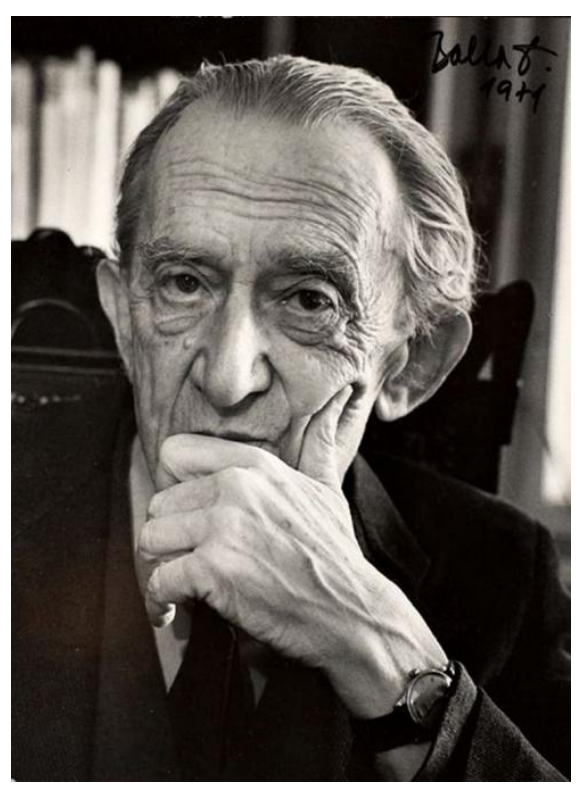

Georg Lucacs

gerçeklik kuramının farklılık göstermesidir. Ona göre "gerçekçilik 'realizm' diğer sanat dalları gibi ele alacağımız bir akım değildir. Yani kuram olarak gerçekçilik ile sanat akımı olarak gerçekçilik aynı şeyler değildir. Kuram olarak bakıldığında tüm sanat akımları gerçekçidir ve bu durum asla belli bir yüzyılın estetik programının tekeline indirgenemez. Gerçeklik kavram olarak, sanatın temelidir; tüm diğer akımlar onun içinden doğar ve onunla olan ilişkileri çerçevesinde anlam kazanırlar. Tüm sanat türleri, diğer edebî türler gibi toplumsal ve tarihsel gerçeklikleri yansıtırlar; modernin bunu yansıtma biçimi sadece daha çarpık ve çapraşıktır." (Antakyalıŏlu 2013: 53-54) Ayrıca Lukacs gerçekçiliği roman açısından değerlendirirken, romanın hangi akımda yazılırsa yazılsın gerçekçiliğin ideolojilere göre farklı tavırlar sergileyebileceğini belirtir. Bütün edebî eserlerin temel konusu insandır. Roman da insanın hikâyesini anlatır. Hikâye, bireyin yaşadıklarından oluşur. Lukacs'a göre roman, Aristoteles'in yaptığı insan tanımına göre gelişir: "Aristoteles'e göre insan sosyal bir hayvandır. Roman, insanı hem bir varlık olarak, hem de içinde yaşadığı toplumla birlikte düşünmek zorundadır. Gerçekçilik bu varlığın ele alınış biçimi bakımından farklılıklar geliştirmiştir." (Antakyalığlu 2013: 57)

Toplumcu gerçekçilikten hareket edenler, sanatı bir yansıtma vasıtası olarak görürler. Onlara göre yansıtma kuramı tarihsel süreç ile toplumsal yapıyı ve çalışma koşullarını içermelidir. Bu bakış açısı, Marksist anlayıştan kaynaklanır, onlar toplumun geçirdiği değişim ve evreleri dikkate alır. Sanatı yansıtma olarak kabul edenler arasında da birlik yoktur. "Bazılarınca bu, yüzeysel gerçeklikti, bazılarınca insan tabiatının özü, bazılarınca idealleştirilmiş gerçeklik, yine bazılarınca toplumun günlük hayatıydı. Toplumcu gerçekçilik bunlardan en çok sonuncusuna, yani gerçekçilik akımına yakındır (Moran 1981: 40)

"Tüm sanatlar ve akımlar gerçekliğin birer taklidi, temsili ve sunum biçimdir.Palton ve Aristoteles'ten günümüze bu tutum, sanat için en belirleyici genellemedir. Peki sanat bize gerçekliği bir ayna gibi mi yansıtır? Aynanın yansıtması ile sanatın göstermesi aynı kavramlar değildir. Sanat bir ayna 'gibi' bize 'realiteyi' yansıtmak istese bile yaptığı şey, gösterme, sunma, yorumlama ve bakış açılarıyla realiteyi/gerçekliği zenginleştirme veya dönüştürmedir. Louis Althusser'in tespitine göre 'sanat dışarıda olan gerçekliğe gönderme yapar, onu kasteder, onu bir ayna gibi direkt olarak değil, dolaylı bir şekilde bize sunar. Sanat görmemizi sağlar. O hâlde sanatın yansıtması bir tür göstermedir ve bu, aynanın yansıtmasından ziyade şeffaf bir camdan öteye bakmak gibi algılanmalıdır. Sanatçı 
ayna tutmaz, gözlük takar diyebiliriz. Ayna saydam değildir; ama sanatın penceresi saydam ve çift yönlüdür." (Antakyalıŏlu 2013: 52)

Bazı eleştirmenler, gerçekliği aynaya indirgemenin doğru olmadığı görüşünü paylaşırlar. Onlara göre ayna tek boyutlu ve tek yönlü eksik bir görüntü sunar. Gerçeklik, bir prizmadır, sanatçı aslında bir prizma ve renk tayfı görevi yapar. Gerçeklik aynı zamanda çoğul ve parçalıdır.

Realist bakış açısından hareket eden birçok ünlü yazar, yaşadığı çağı ve bu çağın karakteristik özelliklerini eserlerine yansitır. Balzac, Dickens, Stendhal ve Tolstoy kendi dönemlerinin sosyal gerçekliğini eserlerine başarıyla aktarırlar. Bu yazarlar, kendi dönemlerini ele alırken tarafsız kalmaya özen gösterirler. Bununla beraber bozuk olan sosyal yapıyı da dile getirmekten çekinmezler. Gerçekçi yazarın ideolojik bakış açısıyla hareket etmemesi, eserini siyasi zemin üzerine kurgulamaması önemlidir. O zaman edebî eser, eser olmaktan çıkar, siyasi bir propaganda malzemesine dönüşür. "Stendhal, romanı yol boyunca(cadde üzerinde) gezdirilen bir aynaya benzetir. Çağdaş romancılar, eserlerinde umumiyetle hayatı aksettirmeyi gaye edinmişlerdir. Böyle olunca hayatta ne varsa, romana bunların hepsi girer. Hatta bir romanın güzelliği, aksettirdiği hayatın zenginliği ile ölçülür. Bununla beraber, hayat o kadar zengin ve çeşitlidir ki, hiçbir roman onu tamamıla içine alamaz; buna imkân yoktur. Her roman, yazarının bakış açısıyla sınırlıdır. Edebiyat ancak bütünü ile ele alınırsa kültüre denk düşer. Nasıl her insan hayatın bir parçası ise, her edebî eser de öyledir. Her edebî eserde hayat ve kültürün bir parçası görünür." (Kaplan 1982: 11)

Gerçekçi bir eser, hayatı ve insanı birçok yönüyle ele almakla birlikte sosyolojik bir nitelik kazanmaz. Fakat sosyoloji bir bilim dalı olarak edebî eserden yararlanabilir. Milan Kundera'ya göre gerçekle hiç alakası olmayan fantastik eserler bile,belli bir zaman diliminin dışında değildir. O, bu konuda şunları söylüyor: "Balzac'tan beri insanın dünyasının romanda da, tarih ve mekânla belirlenmiş olduğu(dur)...Hatta gerçeğe uygunluğun tüm kurallarını çiğneyen, fantezist ve olmayacak hikâyeler uyduran yazar Gombrowicz bile bu ilkelerin dışında değildir." (Timur 2002: 302)

\section{Türk Edebiyatında Realist Anlayış}

Türk edebiyatının yönünü XIX. yüzyılda Batıya çevirmesi, aydınlara edebî türleri, fikir akımlarını ve siyasi ideolojileri tanıma imkânı sağlar. Batı edebiyatında olduğu gibi bizim edebiyatımızda da sosyal gerçekçilikten hareketle özellikle hikâye ve roman türünde önemli eserler verilir. Tanzimat döneminde bazı akımlar birbirine karıştırılır, hatta realizmle natüralizm (doğalcılık) bir tutulur. Halit Ziya, "hakikiyyûn" terimi(ni) hem gerçekçiler, hem de doğalcılar (natüralistler) için kullanır." (Özkırımlı 1981: 419) Bu dönemde, yazarlar arasında edebî eserler konusunda önemli tartışmalar yaşanır. Bu tartışmalardan biri de 
"Dekadanlar" meselesidir. Ahmet Mithat'a göre yazılan bir eser okur tarafından anlaşılmalıdır. Oysa Servet-i Fünûncuların yazdıklarında bir garabet vardır. Ahmet Mithat Efendi, bu eserleri anlayamadığından yakınır. Halit Ziya'nın 1896 yılında Mai ve Siyah romanını yayımlaması, Türk romanının gelişimi açısından önemli bir gösterge olur. Halit Ziya gibi bir yeteneğin ortaya çıkışı Ahmet Mithat Efendi'nin prestijini sarsar. Kendisi, bunun üzerine "Dekadanlık" sorununu gündeme getirir: "Ahmet Mithat Efendi'nin 22 Mart 1897 tarihinde Sabah gazetesinde çıkan yazısıyla başlayan bu tartışma, zaman zaman şiddetlenerek, zaman zaman şiddeti azalarak 1900

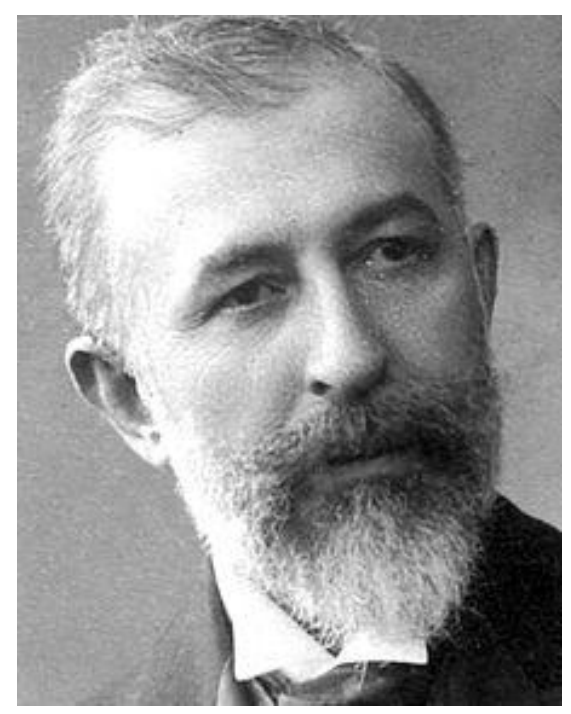

Halit Ziya Uşaklıgil yılı ortalarına kadar devam etmiştir." (Gökçek 2009: 159) "Dekadizm"in geriye gitmek anlamı olduğu gibi, gençlere kötü örnek olma ve ahlakı zaafa uğratma gibi tesirinden de söz edilir. Özellikle bu konuda Cenab Şehabeddin suçlanır. Halit Ziya, Mai ve Siyah romanını realist bakış açısıyla yazar. Romanda "mai" hayalleri "siyah" gerçeği ifade eder. Romanın kahramanı Ahmet Cemil, hayallerine yenilir. Halit Ziya, Hikâye adlı eserinde realist ekol ile ilgili olarak şunları söyler:

\begin{abstract}
"Realist ekol maddeye ve ruha dayanan konuları inceleme ve deneme üzerine bina ederek tasvirden ve çözümlemeden oluşmuştur. [...] Bir realist için başlıca araçlar inceleme ve denemedir, fakat bu iki aracın kullanılması maddeye dayanan konular hakkında ne kolay ise, ruhla ilgili konularda o kadar güçtür. [...] Hayat garip olaylar serisidir, rastlantısal olarak önlerine çıkan durumlara iyice araştırarak bakanlar için her dakika yeni bir durum gösterir. Bir insan nasıl bir çevrede bulunursa bulunsun kendi hayat tarzina benzemeyen hayat sahibine rastlar. Mesela düşmüş bir kız, fakir bir aile, cinayete eğilimli bir adam,duyarlı bir kadın, mutsuz bir karı tanırız; her gün bir başka tarzda yüzler görürüz. [...] Hikâyeci olmamakla birlikte rastladığı çeşitli insanları bekleyen geleceği düşünen veya bir olayın öncesini bilip sonuçlarının ne olabileceğini kurgulayan incelemeciler o kadar çoktur ki hemen hepimiz o incelemecilerden olduğumuzu ileri sürebiliriz. [...] Bir realist bizi şahısların yaşadığı yerlere kadar götürür, en ufak açıklamayı, en küçük ayrıntıyı bize gösterir, hiçbir noktayı suskun geçmez." (1998: 95-101)
\end{abstract}

Halit Ziya'ya göre realist anlayışla eser yazan bir yazar gerçeği bütün ayrıntılarıyla ele alan ve değerlendiren bir niteliğe sahip olmalıdır. Ali Kemâl, edebiyatın bir bilgi ve ihtisas işi olduğunu belirterek, edebiyatımızdaki kargaşadan bahseder: "Her kalem sahibi her telden çalmakla şaîr, hikâye yazarı, bilim adamı, doktor gibi her türlü mesleğe bürünmektedir. Oysa zamanımız ihtisaslaşmaya önem vermekte hatta bunu 
gerektirmektedir. Ali Kemâl'e göre örneğin Nabizâde Nazım Bey edebiyatçılarımızın en zekilerindendi. Ancak asker, şâir, mütefennin, hikâye yazarı özetle ne kadar meslek varsa hepsinden olmuştu. Bunların her birinde bir heves gösteriyor kabarıyordu ama çok kısa zamanda sönüyordu." (2007: 26) Halit Ziya gibi Ali Kemâl de realist ve natüralizmi "hakikiyyûn" terimi ile ifade eder: "Hakikiyyûn edebiyatı" nedir? Asr-1 hâzırınnısf-1 sânîsine doğru edebiyatta bir tebeddül husûle geldi. Hayalden ziyade hakikat meydan aldı. Bu tebeddülü de hazırlayan yine hayaliyyûn oldu." (2007: 50). "Hayaliyyûn"u romantizm kabul eden Ali Kemâl, realizmi hazırlayanların Victor Hugo ve arkadaşları olduğunu belirtir. Ayrıca romantizm olmasaydı realizmin olamayacağını açıklar. Sanat ve edebiyat anlayışında bazı ölçütlerden bahseden Ali Kemâl, bu konuda şunları söyler: "Sanat, fen, edebiyat 'gayr-1 şahsi' olmalıdır. Yazılan şeye insan bir şey koymamalıdır. Kitabında ihtisâsât ve temâyülât-ı zâtiyyesinden dem vurmamalıdır." (2007: 126)

Edebiyatımızda realist eserler, Nabizâde Nazım'ın Karabibik (1890), Zehra (1896); Ahmet Mithat Müşâhedât (1890), "Bahtiyarlık" (1885); Halit Ziya'nın Mai ve Siyah (1897), Aşk-ı Memnu (1900); Mizancı Murat'ın Turfanda mı Yoksa Turfa mı (1890); Ebubekir Hazım'ın Küçük Paşa (1910), Hüseyin'in Cahit Hayat-ı Hakikiye Sahneleri (1910) adlı eserleridir. Hüseyin Rahmi, Refik Halit, Ömer Seyfettin, Yakup Kadri, Reşat Nuri, Halide Edib, Sadri Ertem ve Vakit gazetesinde yazanlar, Memduh Şevket, Sabahattin Ali yine realist çizgiyi izlerler. Ayrıca 1940 sonrası "köy romanı" çizgisinden hareketle ortaya yeni yazarlar çıkar. Bunlar, Reşat Enis, Samim Kocagöz, Sunullah Arısoy, Talip Apaydın, Orhan Hançerlioğlu, Kemal Bilbaşar, Fakir Baykurt vd realist bakış açısıyla yeni eserler kaleme alırlar. Ayrıca bu geleneği sürdürenler arasında "Üç Kemallerin de mühim bir yeri vardır. Orhan Kemal, Yaşar Kemal ve Kemal Tahir, Türk insanını ve Türk köylüsünü ele alan hikâye ve roman yazarlar. Bu romanların karakteristik özelliklerinden biri de "köyün gerçeğe uygun" yazıldığı iddiasıdır: "Bu konuda hemen kabul edilecek bir durum varsa, o da, gerçekten köy romanı yazarlarının, gözlemle yetinen ve yaşadıkları çevrelerin şartlarına bağlı, köylünün yaşayışını hep aynı kalıplar içinde anlatan yazarlar olduklarıdır. Bu bakımdan eserleri de, belli bir dönemin problemleriyle dolu ve o çevrenin şartlarıyla sınırlıdır." (Kaplan 1997: 558-559)

Türk edebiyatında realist anlayış her zaman gücünü korur ve yazarların tercih ettiği bir eğilim olur. Bu durum "kimi zaman, realizm ve romantizmin yalnızca birer edebiyat eğilimi oldukları neredeyse unutulmuş, söz konusu eğilimler birer değer kategorisi olarak algılanmışlardır. Bir yapıt 'ne kadar gerçekçi' diye övülürken, bir diğeri için ise 'romantik' sözcüğü estetik bağlamda değersiz anlamında kullanılmıştır... Cumhuriyet sonrası Türk romanında eğilimin dışına çıkan örnekler az da olsa kuşkusuz vardır. Halit Ziya Uşaklıgil'in Aşk-ı Memnu'sundaki bireysel iç dünya yolculukları; Ahmet Hamdi Tanpınar'ın Saatleri Ayarlama Enstitüsü'ndeki öznel zaman kavramı ya da Attilâ İlhan'ın 'flashback' tekniğiyle 


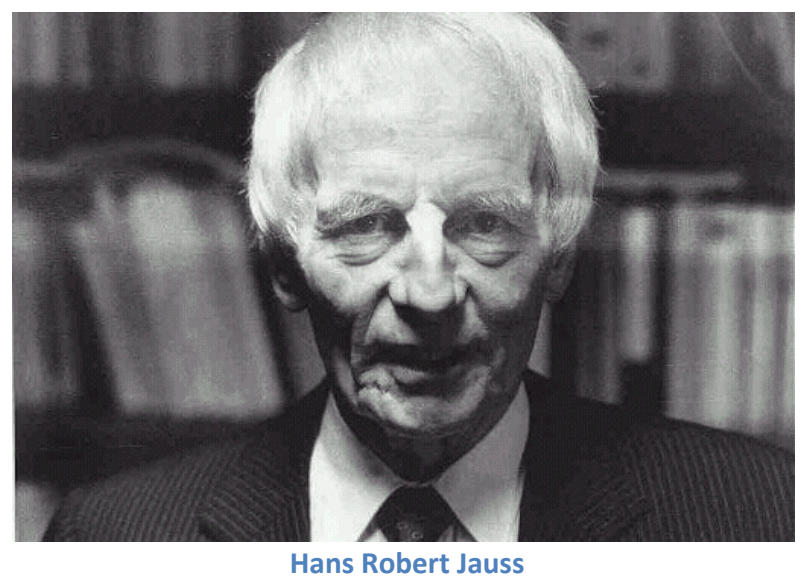

geçmişe dönerek zamandizinsel anlatımı delme gibi özellikler buna örnek olarak gösterilebilir." (Ecevit 2004: 84)

Özellikle 1950 sonrası hikâye ve romanda yeni felsefi akımların etkisiyle yazarlar, varoluşçuluk, yeni roman anlayışı ve bilinç akımı tekniği doğrultusunda yeni gerçekçilik diyeceğimiz bireyin iç dünyasına dönük eserlere yönelirler. Bu anlayış bir nevi gerçekliğin boyut değiştirmesi olur. 1970'li yıllardan itibaren roman anlayışında kent olgusu ve bireyin sorunları ön plana çıkar. Bu romanlarda modern ve postmodern özellikler bir arada bulunur. "Türk edebiyatında modernist romanın öncüsü Oğuz Atay'dır. Atay 1972'de (Tutunamayanlar), o güne değin Türk edebiyatında kurgu/biçim özellikleri açısından görülmemiş bir romanla ortaya çıkar. (86) Çok katmanlı roman örneğinin ilklerinden olan Tutunamayanlar ile birlikte yeni romanda gerçekçilik anlayışı değişir. Roman artık bir yansıtma görevi yapmak yerine gerçekliği "yabancılaştırarak" yeniden kurar. Batı romanında olduğu gibi Türk romanında da "çok katmanlı", "açık yapıt" diye adlandırılan postmodern eserler ortaya çıkar.

\section{Alımlama Estetiği}

Bir sanat eserinin özellikle bir edebî eserin okur tarafından anlaşılması, bir değer olarak ortaya çıkması ve kabul görmesi önemlidir. Edebî eseri, okursuz düşünemeyiz. Alımlama estetiği her şeyden önce okuru öne çıkaran yeni bir edebiyat kuramıdır. Jauss'ın yaklaşımına göre "edebiyat olayı karşısında bugüne kadar başlıca iki yaklaşım saptayabiliriz. Biri, Marksist yaklaşım, öbürü de formalist yaklaşım. Her iki anlayışın da ortak yönü vardır. Onlar, edebiyat olgusunu belli bir açıdan ele alırlar. Onlar için edebiyat yapıtı bir üretimdir ya da bir betimlemedir. Ama bunun dışında başka bir şey değildir (Tunalı 2001: 121)." Bu bakış açısı edebî esere yüzeysel bir yaklaşımdır. Bir edebî eser için asıl unsur okuyucudur. Edebî eserin varlık sebebi de okuyucudur. "Burada edebiyat söz konusu olduğuna göre okuyucu etkisi ön planda gelmelidir. [...] Yeni bir yapıt üzerine yargı veren eleştirmen de, daha önceki bir yapıtın pozitif ya da negatif kuralları karşısında kendi yapıtını tasarlayan yazar da, bir edebiyat yapıtını gelenek içindeki yerine oturtan ve onu tarihsel açıdan açıklayan edebiyat tarihçisi de ilkin okuyucudurlar. Marksist anlayış okuyucuyu edebiyat olgusunun dişında tutar." (Tunalı 2001: 121)

Alımlama estetiği bir anlama olgusudur. Bu estetik kuramında okur önemlidir. Edebî eseri anlayan, çözümleyen ve değerlendiren okurdur. Alımlama estetiğinin ana omurgasını 
"yazar-metin-okur" ilişkisi oluşturur. Edebî eseri oluşturan yazar "ama yaşamasını sürekli kılan, ona oksijen sağlayan okurdur...Yapıt her yeni okurla yüzleştikçe yeni bir ruh, yeni bir anlam kazanır." (Özbek 2013: 15) Hilmi Yavuz, okurla ilgili değerlendirmesinde Stanley Fish'in eserinden yola çıkarak şunları söyler: "Metni anlamlandıran okurun kendisiymiş gibi görünse de okur, 'toplumda içinde yaşadığı ve değerlerini benimsediği kesimin dayattığ 'yorumlama stratejileri'nin belirlediği konumdadır. 'Yorumlama stratejileri' okumanın biçimidirler ve okumanın biçimi oldukları için de, metne biçimini verirler." (Yavuz 2012: 21) Okuyucunun kendine özgü kişiliği, bilgi birikimi, yetiştiği kültür ortamı ve dünya görüşü, edebî eseri değerlendirme ve yorumlamada belirleyici bir rol oynar. Okur tarafından yapılan her farklı yorum ve değerlendirme edebî eserin zenginleşmesi demektir. Edebî eserin kalıcılığı ve değeri okurun ona verdiği itibara bağlıdır. Edebî eserin muhatabı her zaman okurdur. Alımlama estetiği, edebiyat tarihi bakımından da önem arz eder. Edebî eserin, edebiyat tarihi içindeki yerini, okur belirler. Tarihi süreç içinde yorumlar ve bakış açıları değişmekle birlikte alımlama estetiği belirleyici unsur olur.

"Alımlama estetiğine göre her sanat yapıtı, arka planına, bu alanlardaki karanlık odalara açılan kapıların anahtarını kendi cebinde taşır; her birinin birçok kapısı, birçok anahtarı olabilir." (Özbek 2013: 31) Bu kapıların anahtarını bulmak ve o kapıları açmak görevi okura kalmaktadır. Bazen kendi zamanı ve dönemi içinde okur tarafından anlaşılmayan bir edebî eser, yine daha sonraki dönemlerde anlaşılabilir ve hak ettiği değeri alabilir. Umberto Eco'ya göre bir edebî eserin değeri "açık yapıt" olmasına bağlıdır. "Açık yapıt"la kastedilen edebî eserin veya bir sanat eserinin sınırlandırılmış bir anlam yerine sayısız anlam ifade edecek bir zenginlik kazanmasıdır. Günümüzde alımlama estetiği ile çoğul bakış açısı ve okurun önemi arttı. Postmodern anlayışla beraber okur edebî esere zenginlik katar ve onu daha popüler hâle getirir.

Alımlama estetiği ile ortaya çıkan bir başka gerçek de okur vasıtasıyla edebî eserin kitleleri etkileme gücüdür. Yazar, edebî eseri oluştururken gerçeği yansıtmaya çalışsa da onu kendi zihninde yeniden kurgular ve yeniden dönüştürür. Hangi akım ve kuramda olursa olsun, edebî eser bazen öncü ve izleyici işlevi görür. Son yıllarda siyasi, sosyal ve kültürel alandaki hızlı gelişmeler insani bilimlerdeki değişimi etkilemekte ve yeni oluşumlara zemin hazırlamaktadır. Bununla birlikte, hangi dönemde olursa olsun okur tarafından itibar gören edebî eserler topluma nüfuz etmekte, toplum üzerinde önemli tesirler bırakmaktadır.

Halit Ziya Mai ve Siyah romanını yayımladıktan sonra romanın okurda bıraktığı etki karşısında "hayatı romanlar yapıyor" diyecektir. Goethe'nin Genç Werther'in Acıları romanı Avrupa'da intiharların artmasına neden olacaktır. Ayrıca W.Hugo'nun Sefiller romanı da çarpıcı etki uyandıracaktır. Bu eserler yayımlandığında kitle iletişim araçları bugünün koşullarına göre çok daha ilkel ve çok daha azdı. Hatta 1949 yılında basılan Tanpınar'ın 
Huzur romanı, yetmişli yıllardan sonra okurlar tarafından keşfedilir, Tanpınar'a olan ilgi ve sevgi bu sayede giderek artar. Aynı durum Oğuz Atay'ın Tutunamayanlar romanı içinde söylenebilir. Bütün bunlar alımlama estetiğinin ortaya çıkan sonuçlardır.

\section{Sonuç}

Sanat eserleri, sanatçının kendine özgü yorumuyla biçimlendirip anlam kazandırdığ1 eserlerdir. Sanat eserlerinin ortaya çıkışında birtakım oluşumların etkisi görülür. Bunlar, inançlar,gelenekler ve felsefedir. Sanatın konusu genelde insandır.Bununla birlikte edebiyat ve sanat eserlerinin konuları siyasi, sosyal ve kültürel yapıya bağlı olarak değişimler gösterebilir. Platon ve Aristo'dan günümüze kadar edebiyatın birey ve toplum üzerindeki gücüne inanılır. $\mathrm{Bu}$ yönüyle edebiyat toplumun şekillenmesinde, ortak değerlerin oluşumunda etkin bir güç olarak görülür. Toplum, edebiyat sayesinde geçmiş ile gelecek arasında bağ kurar ve edebiyat vasıtasıyla kültürel değerleri gelecek kuşaklara aktarır. Edebiyat, bu işlevini yerine getirirken onun iki farklı yönü üzerinde durulur. Bunlardan birincisi, edebiyata kişisel duygu ve yaşantıların ifadesi olarak değerlendirenler, ona estetik bakış açısından bakanlardır. İkincisi ise, edebiyatı sosyal gerçekleri dile getiren ve toplumla ilgili sorunların çözümünde bir vasıta olarak görenlerdir.

Edebî eser, kendi döneminin ruhunu ve dünya görüşünü yansitır. Bu ruhun oluşumunda felsefe geleneğinin ve sanat kuramlarının önemli rolü vardır. Batıda sanat kuramlarını besleyen ve zenginleştiren de felsefedir. Felsefi düşünüş biçimi edebî eserlere bakış açısı zenginliği ve derinlik katar. Özellikle XIX. yüzyılda Batıda gelişen pozitivizm, realist bakış açısını ve sosyal gerçekliği ön plana çıkarır. Aslında pozitivizm dinin yerine ikame edilmeye çalışılan bir felsefi anlayıştır. Pozitivizmin etkisiyle edebî eserin gerçeği anlatması gerektiğini savunanlar ona "sosyolojik bakış açısı"yla yaklaşanlardır. Gerçekçi edebiyatta insan, çevresini ve kendini değiştirebilendir. İnsanın hayatına yazar müdahale etmez.

Edebiyat kuramları ve akımları birbirine tepki olarak ortaya çıkar. Edebî eser, hangi kuram yazılırsa yazılsın alımlama estetiği sayesinde varlık kazanır ve o, okur vasıtasıyla geniş kitlelere ulaşır.

\section{Kaynakça}

Ali Kemal (2007). Edebiyât-ı Hakikiyye Dersleri. Haz. Bahriye Çeri. Ankara: Hece Yayınları. Antakyalığlu, Zekiye (2013). Roman Kuramına Giriş. İstanbul: Ayrıntı.

Eagleton, Terry (2015). Edebiyat Nasıl Okunur. Çev. Elif Ersavcı. İstanbul: İletişim Yayınları. Ecevit, Yıldız (2004). Türk Romanında Modernist Açılımlar. İstanbul: İletişim Yayınları. 
Eliot, T. S. (1983). Edebiyat Üzerine Düşünceler. Çev. Sevim Kantarcıŏlu. Ankara: Kültür ve Turizm Bakanlığı Yayınları.

Gökçek, Fazıl (2009) Bir Tartışmanın Hikâyesi Dekadanlar. İstanbul: Dergâh Yayınları.

Kantarcıoğlu, Sevim (1983). Edebiyat Akımları ve Temel Metinler. Ankara: Gazi Üniversitesi Teknik Eğitim Fakültesi Yayınları.

Kaplan, Mehmet (1982). Kültür ve Dil. İstanbul: Dergâh Yayınları.

Kaplan, Ramazan (1997). Cumhuriyet Dönemi Türk Romanında Köy. Ankara: Akçağ Yayınları.

Kefeli, Emel (2007). Metinlerle Edebiyat Akımları. İstanbul: 3F Yayınevi.

Moran, Berna (1981). Edebiyat Kuramları ve Eleştiri. İstanbul: Cem Yayınevi.

Özbek, Yılmaz (2013). Postmodernizm ve Alımlama Estetiği. Konya: Çizgi Kitabevi.

Özkırımlı, Atilla (1983). Edebiyat İncelemeleri. İstanbul: Cem Yayınevi.

Taşdelen, Vefa (2013). Felsefeden Edebiyata. Ankara: Hece Yayınları.

Timur, Taner (2002). Osmanl-Türk Romanında Tarih, Toplum ve Kimlik. Ankara: İmge Kitabevi.

Tolstoy, L. N. (2013). Sanat Nedir. Çev. Beyhan, Mazlum. İstanbul: Türkiye İş Bankası Yayınları.

Tunalı, İsmail (2001). Estetik. İstanbul: Remzi Kitabevi.

Yavuz, Hilmi (2012). Okuma Biçimleri. İstanbul: Timaş Yayınları. 